\title{
Canine Rangeliosis: A Rare Case of Hyperparasitemia in the Acute Phase
}

\author{
Danieli Brolo Martins' ${ }^{1}$, Aleksandro Schaffer Da Silva' ${ }^{2}$ Evelyn de Oliveira ${ }^{3}$, \\ Marcelo Bahia Labruna ${ }^{4} \&$ João Fábio Soares ${ }^{5}$
}

\begin{abstract}
Background: $R$. vitalii causes a remerging tick-borne disease known as rangeliosis. The parasite is not always identifiable in blood smears, especially in the chronic phase of the disease. Low parasitemia levels have been observed in cases of rangeliosis caused by natural infection, even in acute situations, while hyperparasitemia has been reported only in acute experimental infection. This paper describes an unusual case of acute natural $R$. vitalii infection with hyperparasitemia. Case: The dog (a 12-year-old male German Shepherd) had presented apathy, dyschezia and hyporexia for three days prior to seeing the veterinarian, whose examination revealed discrete pale mucous membranes, soft bloody stools, hyperthermia, splenomegaly and lethargy. Numerous intra-erythrocytic forms, as well as free-living parasites compatible with $R$. vitalii and/or Babesia sp, were also found in the CBC (complete blood count), and the parasite load was estimated at 12 parasites/ field - x1000. After diagnosing hemoparasitosis from the blood smear, therapy was started immediately. After 18 days of treatment, the animal returned to the veterinary hospital showing visibly improved health. The dog's mucous membranes showed normal coloration. A new CBC showed no intra-erythrocytic parasite in the blood smear. Some of the blood drawn during the animal's first examination was sent for DNA extraction. Two specific TaqMan real-time PCR-based assays were performed to test for $R$. vitalii, and Ehrlichia canis. The sample was also tested for Babesia (Babesia canis and Babesia gibsoni), but tested positive only for $R$. vitalii.

Discussion: Clinical signs related to the disease depend on its acute, subclinical, and chronic evolution, which may be reflected in clinical and pathological conditions. Our dog presented mild clinical signs of the disease, such as apathy, lethargy, hyporexia, hyperthermia, discrete pale mucous membranes, splenomegaly, dyschezia and soft bloody stools. In acute experimental cases, parasitemia increases progressively after inoculation, when $R$. vitalii becomes detectable in erythrocytes and leukocytes. In the chronic form of the disease, it is particularly rare to identify free-living forms of $R$. vitalii in the bloodstream or of the parasite in erythrocytes, and they are identified in only in few cases of natural infection. The blood smear of our canine patient contained numerous parasitized cells, showing different shapes and sizes of the parasite, as well as a variable number of microorganisms parasitizing each cell. The number of parasitized erythrocytes was comparatively higher than that of leukocytes. This case report reveals that acute natural canine rangeliosis with hyperparasitemia is possible, indicating that the acute phase of the disease does not occur only in experimental cases. Although the animal showed nonspecific clinical signs in the acute phase, the blood smear and PCR enabled the detection of the parasite. This leads us to suggest that, to ensure a better diagnosis, treatment and prognosis of rangeliosis, veterinarians should also determine whether the disease is in the acute or chronic stage.
\end{abstract}

Keywords: Rangelia vitalii, natural acute phase, high parasitemia, dogs. 


\section{INTRODUCTION}

Rangelia vitalii causes a remerging tick-borne disease known as rangeliosis [8]. The disease is associated with parasitism in erythrocytes, leukocytes and endothelial cells [4]. The parasite is not always identifiable in blood smears and it is identified in only $4 \%$ of cases of natural infection [3].

Given the difficulty of identifying $R$. vitalii in blood smears [4,5], the diagnosis in some dogs may have to be based on their positive response to antiprotozoal therapy [5]. However, numerous erythrocytes become infected with $R$. vitalii during the acute experimental phase of infection [1], unlike what is observed in naturally infected dogs [9]. This paper describes an unusual case of acute natural $R$. vitalii infection with hyperparasitemia.

\section{CASE}

The dog (a 12-year-old male German Shepherd) lived in the yard of a house in a central area of the municipality of Cruz Alta, Rio Grande do Sul, Brazil. The dog had presented apathy, dyschezia and hyporexia for three days prior to seeing the veterinarian, whose examination revealed discrete pale mucous membranes, soft bloody stools, hyperthermia, splenomegaly and lethargy.

The CBC (complete blood count) showed moderate macrocytic hypochromic anemia, while the total number and the different types of leukocytes, as well as platelet counts, were within references values (Table 1 - Day 1). The blood smear revealed numerous intra-erythrocytic forms, as well as free-living parasites compatible with $R$. vitalii and/or Babesia sp, were also found in the blood smear (Figure 1), and the parasite load was estimated at 12 parasites/ field - x1000 [1]. The total plasma proteins (TPP) concentration was normal. No change was observed in serum biochemistry.

After diagnosing hemoparasitosis from the blood smear, intravenous therapy was started immediately with serum glucose, doxycycline, omeprazole and imidocarb dipropionate. Doxycycline was used because it was not known which piroplasms were involved in the case.

The animal returned to the veterinary hospital showing visibly improved health. The owner reported that the dog was ingesting food and water normally and had regained his normal active behav-

ior. The dog's mucous membranes showed normal coloration. A new CBC also showed improvement in blood parameters (Table 1 - day 18). Although this new blood count still showed Howell-Jolly bodies, no intra-erythrocytic parasite was found in the blood smear.

Some of the blood drawn during the animal's first examination was sent for DNA extraction using a DNeasy Blood \&Tissue Kit (Qiagen ${ }^{\circledR}$, Hilden, Germany), according to the manufacturer's instructions. Two specific TaqMan real-time PCRbased assays were performed to test for $R$. vitalii, as previously described [8], and Ehrlichia canis [2]. The sample was also tested for Babesia ( $\mathrm{Ba}$ besia canis and Babesia gibsoni) (protocol to be published in another paper), but tested positive only for $R$. vitalii.

Table 1. CBC of a dog naturally infected with $R$. vitalii in acute phase.

\begin{tabular}{|c|c|c|c|}
\hline $\begin{array}{c}\text { Acute natural } \\
\text { canine rangeliosis } \\
\text { - CBC }\end{array}$ & Day $1 *$ & Day $18 * *$ & $\begin{array}{c}\text { References } \\
\text { values [6] }\end{array}$ \\
\hline $\begin{array}{l}\text { Erythrocytes } \\
\left(\times 10^{6} / \mu \mathrm{L}\right)\end{array}$ & 3.0 & 5.2 & $(5.5-8.5)$ \\
\hline $\begin{array}{l}\text { Hemoglobin } \\
\quad(\mathrm{g} / \mathrm{dL})\end{array}$ & 8.4 & 12.8 & $(12-18)$ \\
\hline Hematocrit (\%) & 27 & 40 & $(37-55)$ \\
\hline $\operatorname{MCV}(f l)$ & 90 & 77 & $(60-77)$ \\
\hline $\mathrm{MCHC}(\%)$ & 31.1 & 32 & $(32-36)$ \\
\hline TPP (g/dl) & 6.8 & 8.6 & $(6-8)$ \\
\hline $\begin{array}{l}\text { Platelets } \\
\left(\times 10^{3} / \mu \mathrm{L}\right)\end{array}$ & 358.0 & 482.0 & $(200-500)$ \\
\hline $\begin{array}{l}\text { Leukocytes } \\
\left(\times 10^{3} / \mu \mathrm{L}\right)\end{array}$ & 14.1 & 14.8 & $(6-17)$ \\
\hline $\begin{array}{l}\text { Band neutrophils } \\
\qquad\left(\times 10^{3} / \mu \mathrm{L}\right)\end{array}$ & 0.14 & -- & $(0-3)$ \\
\hline $\begin{array}{l}\text { Neutrophils } \\
\left(\times 10^{3} / \mu \mathrm{L}\right)\end{array}$ & 10.29 & 7.99 & $(3-11.5)$ \\
\hline $\begin{array}{l}\text { Lymphocyte } \\
\qquad\left(\times 10^{3} / \mu \mathrm{L}\right)\end{array}$ & 2.26 & 3.08 & $(1-4.8)$ \\
\hline $\begin{array}{l}\text { Eosinophils } \\
\left(\times 10^{3} / \mu \mathrm{L}\right)\end{array}$ & 0.14 & 3.52 & $(0.15-1.25)$ \\
\hline $\begin{array}{l}\text { Monocytes } \\
\left(\times 10^{3} / \mu \mathrm{L}\right)\end{array}$ & 1.27 & 0.48 & $(0.15-1.35)$ \\
\hline
\end{tabular}




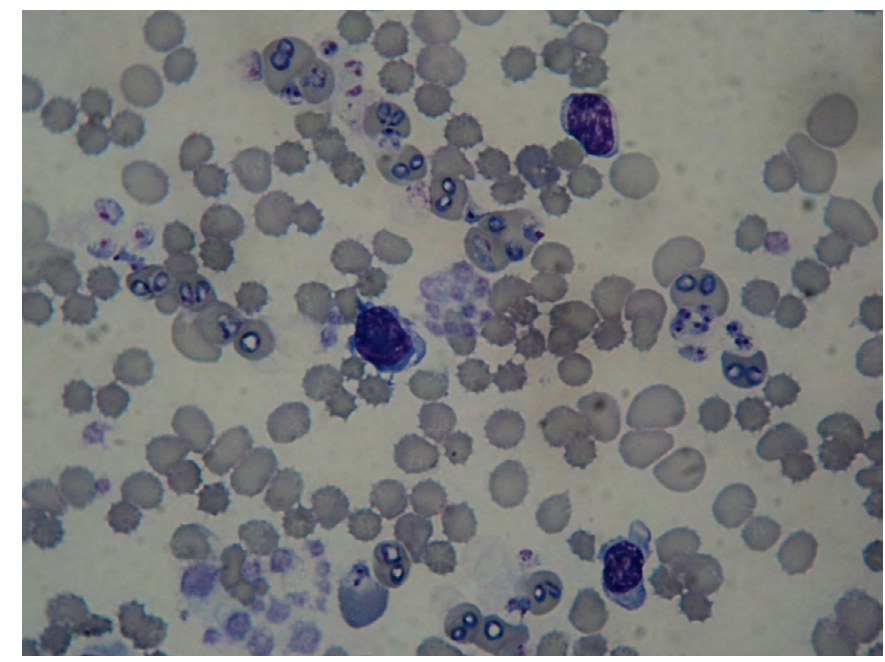

Figure 1. Blood smear of the patient (12-year-old male German Shepherd $\mathrm{dog})$, demonstrating a large number of intra-erythrocytic forms and also free parasites compatible with $R$. vitalii and/ or Babesia sp. (Diff Quick, 1000x).

\section{DISCUSSION}

Our dog presented mild clinical signs of the disease, such as apathy, lethargy, hyporexia, hyperthermia, discrete pale mucous membranes, splenomegaly, dyschezia and soft bloody stools. The large number of intravascular parasites found during the period of the patient's disease was also observed in an acute experimental study with clinical manifestations of hyporexia, hyperthermia and alterations in cardiac frequency. Clinical signs related to rangeliosis depend on its acute, subclinical, and chronic evolution, which may be reflected in clinical and pathological conditions [1].

Anemia is a remarkable finding in many cases $[3,4]$. The dog in this study presented macrocytic hypochromic anemia and other moderate signs of regeneration, but the initial $\mathrm{CBC}$ showed no signs of hemolytic disease. However, the second $\mathrm{CBC}$ revealed discrete evidence of extravascular hemolysis such as spherocytes, although our patient showed no signs of jaundice in plasma or mucous membranes.

TPP levels were within the reference value at the time of diagnosis of the patient. However, it is worth noting that hyperproteinemia was detected 18 days after treatment. The increase in protein levels in the 18-day interval may have been a response to combat the parasite either directly (through the production of immunoglobulins) or indirectly (by activating other cells), similar to what occurs in other parasitic diseases [7], since the dog presented eosinophilia in the second CBC [6]. Thus, it is possible that TPP levels vary as the disease develops.
In experimental cases, parasitemia increases progressively from day 5 to day 11 (peak) after inoculation, when R. vitalii becomes detectable in erythrocytes and leukocytes. After this period, between 13 and 21 days post-inoculation, dogs show more significant clinical signs, while the parasite load decreases and becomes undetectable in the blood smears of some animals [1].

The erythrocyte cycle of the parasite occurs in the acute phase of the disease, facilitating its visualization in blood smears of experimental cases when there is hyperparasitemia [1], unlike what has been reported by other authors in natural cases of the disease, even in acute situations [9]. The blood smear of our canine patient contained numerous parasitized cells, showing different shapes and sizes of the parasite, as well as a variable number of microorganisms parasitizing each cell. The number of parasitized erythrocytes was comparatively higher than that of leukocytes.

This case report reveals that acute natural canine rangeliosis with hyperparasitemia is possible, indicating that the acute phase of the disease does not occur only in experimental cases. Although the animal showed nonspecific clinical signs in the acute phase, the blood smear and PCR enabled the detection of the parasite. The characteristics observed in this case reveal similarities with acute experimental cases $R$. vitalii infection. Although the animal showed nonspecific clinical signs in the acute phase, the blood smear and PCR enabled the detection of the parasite. This leads us to suggest that, to ensure a better diagnosis, treat- 
ment and prognosis of rangeliosis, veterinarians should also determine whether the disease is in the acute or chronic stage.
Declaration of interest. The authors report no conflicts of interest. The authors alone are responsible for the content and writing of the paper.

\section{REFERENCES}

1 Da Silva A.S., França R.T., Costa M.M., Paim C.B., Paim F.C., Dornelles G.L., Soares J.F., Labruna M.B., Mazzanti C.M., Monteiro S.G. \& Lopes S.T. 2011. Experimental infection with Rangelia vitalii in dogs: acute phase, parasitemia, biological cycle, clinical-pathological aspects and treatment. Experimental Parasitology. 128: 347-352.

2 Doyle C.K., Labruna M.B., Breitschwerdt E.B., Tang Y.W., Corstvet R.E., Hegarty B.C., Bloch K.C., Li P., Walker D.H. \& McBride J.W. 2005. Detection of medically important Ehrlichia by quantitative multicolor TaqMan real-time polymerase chain reaction of the dsb gene. The Journal of molecular diagnostics. 7: 504-510.

3 Fighera R.A. 2007. Rangeliose. Acta Scientiae Veterinariae. 35: 261-263.

4 Fighera R.A., Souza T.M., Kommers G.G., Irigoyen L.F. \& Barros C.S.L. 2010. Patogênese e achados clínicos, hematológicos e anatomopatológicos da infecção por Rangelia vitalii em 35 cães (1985-2009). Pesquisa Veterinária Brasileira. 30: 974-987.

5 Loretti A.P. \& Barros S.S. 2005. Hemorrhagic disease in dogs infected with an unclassified intraendothelial piroplasm in southern Brazil. Veterinary Parasitology. 134: 193-213.

6 Meinkoth J.H. \& Clinkenbeard K.D. 2000. Normal hematology of the dog. In: Feldman B.F., Zinkl J.G. \& Jain N.C. (Eds). Schalm's Veterinary Hematology. 5th edn. Philadelphia: Lippincott Williams \& Wilkins, pp.1057-1063.

7 Paim F.C., Da Silva A.S., Paim C.B., França R.T., Costa M.M., Duarte M.M., Da Silva C.B., Mazzanti C.M., Monteiro S.G. \& Lopes S.T.A. 2013. Serum proteinogram, acute phase proteins and immunoglobulins in dogs experimentally infected with Rangelia vitalii. Veterinary Parasitology. 192: 137-142.

8 Soares J.F. 2014. História natural da rangeliose. 123f. São Paulo, SP. Tese (Doutorado em Epidemiologia Experimental Aplicada às Zoonoses). Programa de Pós-graduação em Epidemiologia Experimental Aplicada às Zoonoses, Universidade de São Paulo.

9 Soares J.F., Girotto A., Brandão P.E., Da Silva A.S., França R.T., Lopes S.T.A. \& Labruna M.B. 2011. Detection and molecular characterization of a canine piroplasm from Brazil. Veterinary Parasitology. 180: 203-208. 